\title{
The Scenery: Dwellings in a Sacro-Soundscape
}

\author{
With Marcel Barnard
}

The modern words of The Passion provide a new language for the message of Jesus.

It is a way to break through the muteness.

LEO FIJEN (head of broadcaster RKK), 5 December 2011

(interview by $\mathrm{MK}$ )

Following the debut of The Passion in 2011, with each new edition, various national media became increasingly interested in a phenomenon that appeared to be simultaneously new, hip and happening. ${ }^{1}$ Could I, as a scholar, please in an interview for radio/television/national newspaper explain how the makers came up with the brilliant idea of staging the narrative of the suffering of Jesus Christ in a musical show? In an effort to downplay the hype, one of the first things I used to say was that annual performance of the passion narrative was, in fact, a centuries-old practice. The recitation of specific Bible passages on the life, suffering and death of Christ went back to at least the 4th century CE. And a passion play in the open, in the market square of a city was not all that new either, as the passion of Christ had been the theme of many medieval religious dramas. Of course, this 21st century telling of the story, with lights, pop

1 This chapter contains material that was previously published as part of Mirella Klomp and Marcel Barnard, "Sacro-Soundscapes", and other material that was published as part of Mirella Klomp, "Joseph \& Jesus. Bible-based musicals and contemporary Passions staged in the public domain: an exploration of a research perspective", Yearbook for Liturgical and Ritual Studies 27 (2011), 49-65. The different authors' contributions to this chapter are as follows: Barnard originally wrote the section 'The changing religious landscape', the subsections 'Appadurai's five -scapes' and 'McAlister's religioscapes', the section 'The study of Sacro-soundscapes', and part of the conclusion. I amended the introduction, and wrote the section on 'Transfer and transformations of the Passion', as well as the subsection 'Soundscapes in Acoustemology and Theology'. I elaborated and adapted the entire text for the purposes of this monograph.

(C) MIRELLA KLOMP, 2020 | DOI:10.1163/9789004442948_004

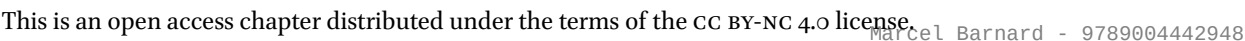


songs, and famous actors and singers on a stage, broadcast live on national TV stations was new and unprecedented but, at the same time, participating in this performance of the Christian passion narrative (in whatever role: as spectator, performer, or organiser) was yet another contextualised form of a ritual practice with distant antecedents in the Christian tradition. This message was often met with surprise, and the interviewers would often then steer the conversation in a different direction.

My typical response was actually a highly-simplified presentation of a development that was more complex than the 30 seconds of time offered in interviews allowed for. Indeed, The Passion is rooted in a longstanding tradition of reinterpretation, reinvention, and reconstruction of the passion form. But in Western cultures a process of transfer and transformation of musical forms rooted in Christian tradition has been going on for a couple of centuries. On top of that, the religious landscape has significantly changed in the past decades. Using the root metaphor of (a) play, we may say that the scenery of the play that we are looking at has altered. This deeply affects the ways in which people attribute meaning to the play, which in turn also has a knock-on effect on practices of religion, as we will demonstrate. After all, plays always take place amidst some kind of surrounding environment, which should, however, not be understood as a fixed backdrop: scenery influences a play, but a play in turn influences the scenery. The scenery in which The Passion is staged is the Dutch religious landscape. The longstanding tradition of reinterpreting, reinventing and reconstructing the passion is a crucial part of its history, its crossings and dwellings, its transfer and transformations.

In this second chapter, we examine what is going on in Dutch society when it comes to religion, by sketching the scenery that forms the backdrop for The Passion. This scenery is characterised by processes of transfer and transformation, thus in order to understand recent developments we must first briefly elaborate the history of the passion as a (liturgical-)musical form. Moreover, we argue that the changing nature of the play (again: as a metaphor for religious forms, language and repertoire) also changes our academic research and disciplines. After all, in order to be able to sketch the scenery of a play, we depend on words, concepts, and metaphors, and we rely on the tools and techniques used in various disciplines when searching for the language most suitable to describe it. Sometimes we find apt and helpful notions, and sometimes we do not. In describing the scenery for The Passion we find ourselves in the latter kind of situation: Christian ritual musical practices have been transferred to extra-ecclesial domains (and back to the ecclesial domain) has been going on, and practical theology - as much as related disciplines like ethnomusicology - lacks appropriate theoretical concepts in order to ade- 
quately interpret these practices. New concepts must, therefore, be developed in order to gain a better and deeper understanding of the phenomenon investigated. In this chapter, we will propose the notion of 'sacro-soundscapes' as an up-to-date theoretical concept for the interpretation of fluid Christian ritual-musical practices in late-modern culture. The fluidisation of these practices results in practical theological research that brings together a range of theories and fields and methods that together serve to create a better understanding of these practices (this very monograph aims to be an example of this development). Fluid practices require research that dares to surpass 'traditional' boundaries of (sub-)disciplines whenever these boundaries do not permit new practices to become the objects of research.

\section{The Changing Religious Landscape}

The Dutch late modern religious landscape is generally characterised by fluidity: it is dynamic more than it is static. Religious language, forms, practices and ritual repertoires over the last century have increasingly left the enclosed domains of the institutionalised churches and have migrated to other realms. Various scholars have characterised this process as a transfer and a transformation of religion and/or the sacred. ${ }^{2}$ Such relocations of Christian immaterial heritage take place against the background of a changing Dutch ecclesial landscape. A perspective from the ground still show the continuation if weekly patters of worship in churches and congregations, however, a bird's eye view on this landscape shows reduction and concentration. Institutionalised Christianity shows a downward trend. Estimations indicate that every week one or two churches and/or monasteries in the country are closed down. ${ }^{3}$ In the past two decades, churches lost on average 267 members per day. ${ }^{4}$ The 2004

2 Joep de Hart, "Summary. Keeping the faith?" The Dutch and their gods. Secularization and transformation of religion in the Netherlands since 1950, ReLic 3, ed. Erik Sengers (Hilversum: Verloren, 2005). Also (in Dutch) Joep de Hart, Maak het nieuw. Over religieuze ontwikkelingen en de positie van de kerken. Een persoonlijke geschiedenis (Den Haag: The Netherlands Institute for Social Research, 2011) (inaugural address Protestant Theological University); Paul Post, "Heilige velden. Panorama van ritueel-religieuze presenties in het publieke domein", Tijdschrift voor Religie, Recht en Beleid 1, no. 3 (2010), 70-91; Erik Borgman, Metamorfosen. Over religie en moderne cultuur (Kampen: Klement Pelckmans, 2006); Van de Donk, Geloven in het publieke domein; Willem Frijhoff, Heiligen, idolen, iconen (Nijmegen: SUN, 1998), 35-38 (inaugural address vu University Amsterdam).

3 De Hart, Geloven binnen en buiten verband, 5 .

4 De Hart and Van Houwelingen, Christenen in Nederland, 40-41. 
merger of the two main Reformed churches of the country together with the Lutheran church, into a single Protestant Church is a striking example of the concentration to which we refer. Christianity in general has lost ground and, accordingly, church attendance has significantly decreased. ${ }^{5}$ This pattern is not typically Dutch in nature, other Western-European countries show similar developments, as does the United States. ${ }^{6}$

Yet, this downward movement of institutionalised Christianity does not automatically signify that the Dutch have all become atheists, although agnostics now form the largest group when it comes to the worldviews held by the population. ${ }^{7}$ Rather, as historian Peter van Rooden put it, Christianity simply became irrelevant due to the rise of a 'reflexive and expressive self'. What remains is apparently a 'basic sacral' ${ }^{9}$ attitude and behaviour, whilst a new group of unaffiliated 'floating believers' has also arisen. ${ }^{10}$ The number belonging to this group of 'floating believers', however, in no way outweighs the decline of established religion. This 'basic sacral' attitude and behaviour is lived out and performed in several different domains, as Paul Post observes. ${ }^{11}$ Firstly, it is performed in the private domain - for instance by means of profane altars and memorial corners in private homes, or home rituals around birthday parties or childbirth. ${ }^{12}$ Secondly, it is played out in the public domain - think of the flowers and improvised crosses which mark the location where someone died in an accident - but also of the 'casual sacrality' found in suburbs at places where art, history, and nature emerge as places

In the last ten years in both the Roman-Catholic Church and the Protestant Church in the Netherlands, church attendance has decreased by more than $35 \%$. "Kerncijfers", KASKI Radboud Universiteit, http://www.ru.nl/kaski/onderzoek/cijfers-overige/virtuele _map/kerncijfers-2012/. Last accessed May 10, 2020.

6 The Pew Research Center, for instance, states that the same trend is seen in the USA. Cf. Pew Research Center, America's Changing Religious Landscape.

7 Bernts and Berghuijs, God in Nederland 1966-2015, 64-65. More on changes in (Christian) religion and worldviews in Chapter 3 .

8 Peter van Rooden, "Oral History en het vreemde sterven van het Nederlandse christendom" [Oral History and the Strange Death of Dutch Christendom], Bijdragen en Mededelingen betreffende de geschiedenis der Nederlanden 119 (2004), 524-551, 547f.

Goedroen Juchtmans, Rituelen thuis: van christelijk tot basaal sacraal. Een exploratieve studie naar huisrituelen in de Tilburgse nieuwbouwwijk De Reeshof, Netherlands Studies in Ritual and Liturgy 8 (Groningen/Tilburg: Instituut voor Liturgiewetenschap/Instituut voor Rituele en Liturgische Studies, 20o8), especially 306-316 and 379-386.

10 Cf. De Hart and Dekker, "Floating Believers", 71-79.

11 Post, "Heilige velden".

12 Juchtmans, Rituelen thuis. 
with special meaning. ${ }^{13}$ Thirdly, it exists also in the cultural domain - in the numerous performances of Bach's St. Matthew's Passion which take place every year, as well as the passion that I use as a case in this book, but also in literature, movies, and art exhibitions in museums and galleries. ${ }^{14}$ Fourthly, a 'basic sacral' attitude and behaviour occurs in the domain of nature, for example in a spiritual centre within natural nature reserves, or in gardening. ${ }^{15}$ And lastly, it can be found in the domain of health and healing: practices of yoga, sports, wellness, etc. serve as examples here, and the international cosmetics brand Rituals, for instance, saw and successfully exploited this niche.

In summary, we can agree with Peter van Rooden, in saying that "Christendom has collapsed in the Netherlands". ${ }^{16}$ We need to add, however, that religion - and even Christian religion - has remained, but has taken a completely different form. Christian religion has been transferred - moved to another place $^{17}$ - from the institutionalised ecclesial domain to several other domains in the wider culture. This transfer has gone hand in hand with the transformation of Christianity into a less specific religion with Christian elements or roots, it has undergone a marked change in form or appearance. ${ }^{18}$ The boundaries of churches are permeable; religion can no longer be measured by facts

13 Inez Schippers, Sacred places in the suburbs. Casual sacrality in the Dutch VINEX-district Leidsche Rijn, Netherlands Studies in Ritual and Liturgy 16 (Groningen/Amsterdam: Institute for Christian Cultural Heritage/Institute for Ritual and Liturgical Studies, 2015).

14 For research on basic-sacrality in music cf. Mirella Klomp, "Die "Passion-zum mitsingen". Christliche Musik im öffentlichen Raum”, in IAH Bulletin 41 (2013), 97-110 [published in 2015]; Martin Hoondert, "The Interpretation and Experience of the Requiem in Contemporary Culture", Yearbook for Ritual and Liturgical Studies 31 (2015), 133-147; Lieke Wijnia and Mirella Klomp, "Tarenskeen's LUTHER. Allowing for New Forms of Sacrality", Yearbook for Liturgical and Ritual Studies 30 (2014), 243-259. On literature see for instance Rein Brouwer, "Theology, Perhaps. A Practical Theological Reflection on Kristien Hemmerechts' Novel The Woman Who Fed the Dogs", International Journal of Public Theology 9, no. 4 (2015), 428-445.

15 Cf. Ruard Ganzevoort and Johan Roeland, "Lived religion: The praxis of practical theology", International Journal of Practical Theology 18, no. 1 (2014), 1-11. DOI: 10.1515/ijpt-2014 -ooo7; and again Schippers, Sacred Places, esp. 107-143.

16 Van Rooden, "Oral History".

17 Definition of "Transfer". Oxford Dictionary. https://www.lexico.com/en/definition/ transfer. Noun, meaning 1. Last accessed May 10, 2020. In the transfer of large musical forms, this act of moving is initiated by composers, conductors, or directors of music ensembles, among others.

18 Definition of "Transformation". Oxford Dictionary. https://www.lexico.com/en/ definition/transformation. Noun, meaning 1. Last accessed May 10, 2020. With the transfer of a musical form to another context, this form becomes the subject of creative appropriation, i.e. transformation. To avoid misunderstandings of the concepts, we here 
and figures on 'traditional' practices such as church attendance, but has become fluid. 'Liquid modernity' calls forth a 'liquid church.'. ${ }^{19}$ This transfer of religion to the 'extra-ecclesial' domain is part of a broader cultural development: in liquid societies, change and flexibility have generally taken the place of continuity and stability, as well-known sociologist Zygmunt Bauman has extensively argued. ${ }^{20}$ In such societies, religion too has become more flexible and fluid.

It should be noted that such evolution inevitably causes counter movements: instability evokes a desire for stability, fluid religiosity calls forth resistance identities that draw clear boundaries, flows of meaning produce counter movements of 'refundamentalisation', particularly among young church members, who tend to be more orthodox than older generations. ${ }^{21}$ Individuals often respond by clinging more firmly to fixed and shared convictions and beliefs. ${ }^{22}$ Late-modernity is driven by ambivalent forces of globalisation and particularisation, connectedness and rootedness. ${ }^{23}$

\section{Transfer and Transformations of Passion Practices}

The Passion is a good illustration of the broader trend by which Christian religious language, forms, practices and ritual repertoires are on the move to

would like to indicate that we do not use the concept 'transformation' in the sense of music having a transformative power (often also referred to as a 'transporting' power). Although music may certainly bring about changes, particularly within people involved in making or listening to music, and although this may be one of the meanings attributed to the music as it is performed, we do not intend to focus on the transformative aspect of music itself. Transformation, as we use the concept in this article, has music itself as its object.

19 Cf. Zygmunt Bauman, Liquid Modernity (Cambridge: Polity, 20oo); Pete Ward, Liquid Church (Carlisle: Paternoster Press, 2002).

20 'Ecclesial' in this chapter is taken in the sense of 'institutionalised church'. By no means do we intend to confine ecclesia to institutionalised churches - we are well aware of and agree with Martin Luther's basic axiom 'ubi verbum ibi ecclesia' (cf. Martin Luther, D. Martin Luther's Werke, Weimarer Ausgabe 40 (Weimar: Boehlau, 1911), 21-23) - but we mean instead to refer to a realm where institutionalised churches shape their own practices, or their use of objects or symbols for that matter. The practices that we describe and refer to in this article are practices in which institutionalised churches have no say because these take place in the cultural or public or 'outer-ecclesial' domain.

21 De Hart, Geloven binnen en buiten verband, 84-86; De Hart and Van Houwelingen, Christenen in Nederland, 58-59.

22 Barnard c.s. call this 'resistance identity' in Barnard, Cilliers, Wepener, Worship in the Network Culture, 13; 74-76.

23 Barnard, Cilliers, Wepener, Worship in the Network Culture, 1. 
'outer-ecclesial' domains. Although the Passion is first and foremost a practice, a brief look at the history of Passion practices and how these have influenced the Passion as a musical form or play, from distant antecedents to its contemporary transfers and transformations, is worthwhile. This makes it clear that current practices stand in a long tradition within the Christian religion. It is worthwhile to look into how these practices have developed over time, and the ways in which they have influenced what Passions have sounded (and looked) like.

Performances of the Passion originate from the recitation of specific Bible passages on the life, suffering and death of Christ that particularly occurred during Holy Week. ${ }^{24}$ From the 5 th century onwards, these Lessons resounded within the liturgy. A characteristic feature of this practice of recitation is that texts are divided into indirect and direct speech: the performance is a narrative which, at times, alternates with quotations. Both Passion practices themselves and the meaning that they have taken on have changed over time and have differed depending on the context. The pilgrim Etheria (also known as Aegeria) in the 4 th century reported that during Holy Week in Jerusalem the reading of the Passion played a significant part in liturgy. This practice was an act of memoria, meant to call to remembrance what happened to Christ, and was participated in with strong commitment. ${ }^{25}$ Around the same time (in the 4th and 5 th centuries) in the West, performances of Passions had another meaning. To St. Augustine, for instance, reading the Passion meant more than simply remembering: it consisted instead of doctrina and contemplatio, which required both solemn reading and solemn celebration. ${ }^{26}$ This brought about a kind of 'objectified performance': the text was recited with an intonation, and became a simple recitative that was not intended to invoke compassion, but proclaimed an act of God-willed suffering, intended to reconcile and liberate the people. Almost a millennium later, in the 13th and 14th centuries, Christ's suffering on the cross began to take greater prominence in Passion practices. As well as performed doctrine, the Passion also became a performance of compassio. ${ }^{27}$ This development in theology and devotion musically resulted in more-dramatic

\footnotetext{
24 This subsection largely draws on Kurt von Fischer, Die Passion. Musik zwischen Kunst und Kirche (Kassel 1997).

25 Von Fischer, Die Passion, 14.

26 Von Fischer, Die Passion, 14. St. Augustin in sermon 218 writes: "Passio Domini et Salvatoris nostri Iesu Christi (...) sollemniter legitur sollemniter celebratur". Text from H.R. Drobner, Augustinus von Hippo. Predigten zum Österlichen Triduum (Sermones 218-229/D). Einleitung, Text, Übersetzung und Anmerkungen, Patrologia, Beiträge zum Studium der Kirchenväter 16 (Frankfurt am Main: Lang, 2006), 124.

Von Fischer, Die Passion, 23-26.
} 
Passion performances as the sung Passion increasingly took on the form of theatrical performances by several people, and - in Germany, England, Italy and Spain from 1470 onwards - polyphony was employed. ${ }^{28}$ Thus the Passion performances of the late 15th century, but more-particularly those of the 16th and 17 th centuries increasingly became performances of imitatio of and sometimes even identificatio with the suffering of Christ. A more intensive religious piety of the people, with a strong focus on the individual and their relation to Christ resulted in a longing to see and hear more, and to do so with greater intensity. ${ }^{29}$ There was greater desire for the actualisation of the Passion and for making it into a reality. The Passion oratorio as musical form thus came into being: a large choral work, consisting of newly composed recitatives (sometimes akin to Gregorian motives), of inserted chorales and non-biblical texts (arias and ariosi) and extensive opening and final parts. Performances of the Passion came to stand for com-passion with an eye to one's own, individual redemption. ${ }^{30}$ The most famous examples of Passion oratorios are, of course, J.S. Bach's St John Passion and St Matthew Passion, which were explicitly intended to be performed in liturgical settings. In 1766, the Lutheran church of Leipzig decided that the Passion narrative should be read in the liturgy, alternating with congregational singing of Passion chorales. ${ }^{31}$ Soon, other cities followed, whilst the Roman Catholic Church retained the age-old tradition of singing a Latin responsorial Passion. Felix Mendelssohn Bartholdy in 1829 was responsible for the rediscovery of Bach's St Matthew Passion. ${ }^{32}$ This performance consisted of a St Matthew Passion that was shortened and cut to half of its original length (so: transformed), an alteration which went hand in hand with a transfer to a new context: performances became part of a charity concert in the concert hall of the Berlin Sing-Akademie. This became an early example of the transfer and transformation of Passion practices, from liturgy and church to concert and concert hall.

In the 2oth century, Passion performances in concert halls became very popular, becoming fully-fledged cultural phenomena, particularly in the

28 Different roles already start occurring in the 1oth/11th centuries, with the development of several lectio tones in Gregorian chant: one for the chronista (the narrator, reciting in indirect speech using the middle register of his voice, thus expressing moderation and objectivity); one for Christus (this part is sung in direct speech and a lower voice symbolising humility), and one for the turbae/synagoga (the crowd, performing in a high voice, thus symbolising the rage of the people).

29 Von Fischer, Die Passion, 26-30.

$30 \quad$ Von Fischer, Die Passion, 79-8o.

31 Von Fischer, Die Passion, 112.

32 Von Fischer, Die Passion, 113-114. 
Netherlands, where, in the same period, the religious landscape began to undergo significant changes, as we elaborated above. Still, the number of newly composed Passions in this period was relatively small, with three potential causes: 1) modern passion music often had a religious (and from the perspective of the arts: restrictive) character, a fact which is related to the way in which the core doctrines of the Christian faith are brought into the discussion; 2) for this reason, Passion music long remained anchored to the Easter period and, therefore, was also dependent on a somewhat limited time-period with the annual calendar; 3) the fascination for Bach's Passions was (and is) unique, a fact which has notably limited the room for new compositions. ${ }^{33}$

The 21st century so far has shown an apparent revival of the Passion form, and, as a consequence, a great variety of Passion performances. To commemorate the 25oth anniversary of J.S. Bach's death in 2000, the Internationale Bach-akademie Stuttgart commissioned Wolfgang Rihm, Osvaldo Golijov, Sofia Gubaidulina and Tan Dun to compose new settings of the narrative for the Passion 2000 project, with each composer choosing one of the four gospels to set. ${ }^{34}$ This resulted in performances of four very different passions, with each composer transforming the passion in their own particular ways. ${ }^{35}$ Passion 2000 may have been an initiative that took away some of the limitations experienced by composers who have often, in the words of composer James MacMillan, "felt Bach hovering over their shoulders". ${ }^{36}$ Whatever the reason, the emergence of many new passion compositions emerged in the first two decades of this century is now a fact. ${ }^{37}$ In the performances of these,

33 Cf. Johan Snel in Marcel Barnard and Gerda van der Haar (eds.), De Bijbel Cultureel. De Bijbel in de kunsten van de twintigste eeuw (Zoetermeer: Boekencentrum, 2010), 530.

34 Billboard, "Score: New Passions", 17. September 29, 2001, https://bit.ly/2q47ybJ. Last accessed May 10, 2020.

35 See the interview with Helmut Rilling in Billboard for details on these transformations. For the Passion 2000 project, cf. Andrew Shenton, "For whom the bells toll. Arvo Part's Passio, metamodemism and the appealing promise of tintinnabulation", in Contemporary Music and Spirituality, eds. Robert Sholl and Sander van Maas (Oxford/New York: Routledge, 2017), 17-36. Also cf. Joanna Cieślik-Klauza, "Passion Music at the Turn of the XX and XXI Centuries, Part I: Sofia Gubaidulina and Wolfgang Rihm", Rocznik Teologii Katolickiej 17, no. 1 (2018), 183-194; Joanna Cieślik-Klauza, "Passion Music at the Turn of the XX and XXI Centuries, Part II: Tan Dun and Osvaldo Golijov", Rocznik Teologii Katolickiej 17, no. 3 (2018), 107-117.

36 Fieldnotes taken on March 18, 2011 during a 'meet the artist'-session with James MacMillan prior to the concert of his St. John Passion in Flagey, Brussels.

37 A somewhat random list of examples: 'St. John Passion' by Gubaidulina (2000), 'DEUS PASSUS (St. Luke Passion)' by Rihm (2000), 'La Pasión según San Marcos' by Golijov (2000), 'Water Passion after St. Matthew' by Dun (2000) - all four part of the Passion 
transformations vary significantly from Jesus Christ as the main character being replaced with a woman whose salvation requires the fall of the entire cosmos (Utopia47:: a very last Passion) on the one hand, to performances of the libretto of the fairy-tale of the little match girl who freezes to death on another, with the match girl's suffering over the course of the passion increasingly coinciding with the suffering of Jesus Christ on the cross, musically symbolised by the insertion of fragments from Bach's St Matthew Passion (Little Match Girl Passion). This great diversity within contemporary appropriations of the passion makes it difficult, if not impossible, to describe a 'general meaning' for Passion practices in the 2oth and particularly the 21st century. This is related to at least two factors: first, compositions that are performed more and more follow from the personal motivations and interests of their composers, which vary between different social, political and religious situations; second, people (composers, performers, and concertgoers alike) increasingly decide for themselves what things mean: they all attribute meaning (including religious meaning) according to their own collection of interpretive frames (see Chapter 7). The way in which religious immaterial heritage such as Christian rituals or, as in our case, a large musical form, is experienced and obtains meaning is affected by the tendency towards individuality that is part of modernity: people deal with these things in their own individual ways, even when the ritual is performed collectively (see Chapters 5 and 7 ).

As has now been demonstrated, Passion practices and their meanings have changed over time and have differed depending on the context. If indeed the transfer and transformation of Christian music practices was already underway in the 19th century, how should we account for the difference of the current situation compared to the past? The key phrase here is 'a changed religious landscape'. For almost a millennium and a half, passions in the Western world were performed in a culture dominated by Christianity. Over the past few centuries, the dominance of Christian faith has gradually changed, but the biggest shift occurred in the 2oth century (in the Netherlands this was particularly linked with the end of pillarisation in the 196os, see Chapter 5). So, today, processes of transfer and transformation surrounding performances of

20oo-project. Afterwards 'Mattheuspassie, een lezing voor 19 zangers' by Tarenskeen (2006), 'Lucas Passie' by Tsoupaki (2007), 'Little Match Girl Passion' by Lang (2008), 'Passio Compassio' by Ensemble Sarband (2010), 'Judas Passion' by Egon Kracht \& The Troupe (2010), 'Utopia47:: a very last Passion' by Blindman/Sleichim (2011), 'St John Passion' (2012) and 'St Luke Passion' (2014) by James MacMillan, 'The Gospel according to the other Mary' by Adams (2013), 'Nasimi Passion' by Franghiz Al-Zadeh (2017). 
the Passion (and of any religious form, language and repertoire for that matter) take place in a culture that generally no longer identifies itself as Christian. This deeply affects the transformations of these musical practices. It also deeply affects the meanings people attribute to passions performed on stage.

Today, most Dutch people sleep in on Sunday morning and never go to church, yet every year on Maundy Thursday, a few million people, in their leisure time participate in this popular show that is based on a Christian narrative. The producer and broadcasting companies have transferred the annual ritual performance of the passion from the liturgy to the city square and transformed it into a media event. The 'lightness' which characterises this passion has given it the nickname of the 'showbiz-passion'. Its process of transformation has hardly touched the narrative (this is still based on the gospels, contrary to transformations in other passion compositions), but lies in its fluidity and link with liquid modernity: in Chapter 1, we indicated that The Passion has a rather fixed format alongside many fluid aspects (music, location, audience, performers, (theological) meaning, motto), which make it an ever-changing dynamic ritual event.

Two misunderstandings might arise here, which may be good to address. The first: that the idea of transformation suggests that there is (or ever was) an original - an absolute point of reference, a central passion form from which all other forms have been derived. There is of course none: even the gospels pass on the narrative of what happened to Jesus Christ in four (more or less) different versions. As we have already mentioned, the Passion is a practice rather than a 'thing', and this means that no two Passions are ever the same. Transformation may be a helpful notion, but only in close connection with the notion of transfer which points to changes relating to performances in a different context than in the past.

The second misunderstanding - the idea that transfer and transformation of the passion is a unidirectional process from church to the broader culture seemingly contradicts the first, but actually points to a paradox. The transformation that comes with the transfer does not necessarily 'stay' in the broader the culture: such a process would be static, rather than dynamic and fluid. Rather, new practices themselves may, like a pendulum, cause other transformations. A very specific example of this is the way in which The Passion, a practice that is itself a result of the transfer to the 'secular' public domain, has in turn changed the liturgical practice of the church. As mentioned in the previous chapter, several parishes and congregations over recent years have embraced The Passion: they have seen the passion narrative performed in a way they could have never invented or executed on their own and, acknowledging its success, they have brought the passion narrative in this new form 
(back in)to the church, either by putting up large screens in the church building to enable people to watch it together via live stream, ${ }^{38}$ or by taking the format of The Passion as an example to create their own local version of The Passion, with local narrators, singers, bands and celebrities. ${ }^{39}$ Either way, The Passion has inhabited various different spaces in the (liturgical) life of the congregations involved. The Passion sometimes serves as a 'ritual supply' complementary to worship, sometimes as a substitute for traditional liturgy. ${ }^{40}$ In other cases, a local Passion has been inserted into the liturgy (for instance in vespers during Holy Week). ${ }^{41}$ In the case of local Passions, parishes have often sought partners for collaboration: with other parishes, but also with primary and/or high schools. Occasionally, Passions have been advertised as an event especially for youth.

In summary, the case of The Passion nicely demonstrates the oscillation of ritual practices and repertoires between the domain of institutionalised churches and the broader culture. It shows how practices that are deeply rooted in and connected with Christianity have changed over time, now taking the form, among other things, of a highly fluid ritual-musical practice. Its particularity lies in its strong connection with both popular culture and liquid modernity: as soon as religion disentangles itself from the bastions of institu-

38 In 2015, this was done in various churches in Enschede, but also throughout the country, e.g. Renkum/Heelsum, Leiderdorp, Berkel en Rodenrijs. Sources: EO/Kro, "Activiteiten", http://www.thepassion.nl/activiteiten. Last accessed August 15, 2016, and "Passions door het hele land", March 30, 2015. Protestantse Kerk in Nederland. http://www.protestantsekerk.nl/actueel/Nieuws/nieuwsoverzicht/Paginas/ Passions-door-het-hele-land.aspx. Last accessed October 30, 2019.

39 "Passions door het hele land", Protestantse Kerk in Nederland. The aim in the case of local versions of The Passion often seems to have shifted compared to the 'original' that aimed to familiarize a broad public with the passion narrative. Locally, the aspects of building the congregation and inviting conversion to Christ become more important. This might explain why quality (of sound, light, performance, etcetera) is sometimes considered of lesser importance. Source: conversation with two groups of Protestant ministers who followed the course "Re-staging the Passion. The Passion Narrative in the Arts", taught by the authors of this chapter at the Protestant Theological University in Groningen and Amsterdam, January-February 2016.

$40 \quad$ In Wijk bij Duurstede in 2015, 'The Passion of Christ' replaced evening prayer in the Protestant Church of Cothen on Tuesday in Holy Week. Source: Rebecca Onderstal (@rebeccaond), Twitter, April 22, 2015, o6:oo p.m., http://twitter.com/rebeccaond. In the Protestant Noorderkerk in Zaandam, there were no traditional services on Wednesday and Maundy Thursday because of their 'PassionZaandam'. Source: Sjaak Visser, e-mail message to MK, April 23, 2015.

41 This was the case in the Protestant congregation of the village Eerbeek. Source: "Passions door het hele land", Protestantse Kerk in Nederland. 
tional religiosity and moves to the squares and market places of late-modern 'secular' society, it immediately becomes influenced by e.g. new forms of commercialisation, visual culture, fandom culture, and media portrayals of contemporary trends. The Passion is not the only example of this transfer and transformation, and we have already discussed other ritual-musical transformations of the Passion. A number of musical examples serve to illustrate this phenomenon more broadly. The rise of Contemporary Christian Music (ссм, or 'relipop' in Dutch), for example, has developed as a full branch of the commercial music industry. In the Netherlands this has been stimulated, in particular, by broadcasting company EO, which has not refrained from using modern means to communicate the gospel. ${ }^{42}$ Festivals of classical, pop and rock music likewise seem to have become a milieu of religious experience. ${ }^{43}$ These can be characterised as examples of the shift from a 'spirituality of dwelling' to a 'spirituality of seeking' to use the sociological terms of Robert Wuthnow. ${ }^{44}$

\section{The Sonic Aspects of Religion}

So far, in sketching the scenery of The Passion, we have described the changing Dutch religious landscape, as well as the history, transfer and transformation of the passion as a musical form and play. The question arises as to how we can theoretically understand fluid religious musical practices such as The Passion. What theoretical concepts can be applied to deepen our understanding of the transition and transformation of large musical forms to 'outer-ecclesial' domains? Searching in the toolboxes of anthropology, religious studies and ethnomusicology, we have found and combined several concepts that we think can be helpful.

42 Since 1974, EO has annually organised the 'EO Youth Day', a large-scale Dutch Christian event that attracts thousands of young people every year. In four decades, this has developed into a an expressive 'hip' event with optimistic biblical one-liners and an evangelical swing. Cf. Johan Roeland et al., "'Can we dance in this place?' Body Practices and Forms of Embodiment in Four Decades of Dutch Evangelical Youth Events", Journal of Contemporary Religion 27, no. 2 (2012), 241-256. DoI: 10.1080/13537903.2012.675736. Also cf. Ronelle Sonnenberg et al., "Shaping Youth Worship. Modes of active participation", Questions Liturgiques 95, no. 3-4 (2014), 216-236.

Heleen Kommers, Hidden in music. An approach to religious experience and pop or rock festivals (PhD diss., Tilburg University). Self-published 2013 (ISBN: 978-94-6108-459-O). Lieke Wijnia, "Making Sense Through Music. Perceptions of the Sacred at Festival Musica Sacra Maastricht" (PhD diss., Tilburg School of Humanities, s.l., 2016).

Wuthnow, After Heaven, 3-4. 


\section{Appadurai's Five - Scapes}

When describing the changing Dutch religious landscape, the word landscape does not simply refer to a specific piece of land or even to the country itself but rather to scenery more broadly, that is to say to the 'design and layout of large spaces.' ${ }^{45}$ It includes all elements of such scenery. The Dutch landscape contains the mill, the green meadows, smaller and larger canals, the poplar trees rustling in the wind, and the sky with clouds that sail along like sailing ships; it is the rain and the sunshine, the wind and the water, and the people moving in this landscape. It is a setting, a décor that can never be captured in one notion. The Indian anthropologist Arjun Appadurai has used the suffix -scapes to define five 'cultural dimensions of globalization' that characterize the current world. ${ }^{46}$ The world is an informational society, in which ideas, cultural values, money, and information move through the network at unprecedented speed. In addition, people are also on the move, be it as labour migrants, as refugees, or as tourists. The World Wide Web and the airport are the preeminent icons of this world, multimedia technology, and modern aircraft comprise the material basis underlying it. ${ }^{47}$ Appadurai (already in 1996) has proposed five -scapes: ethnoscapes, mediascapes, technoscapes, finanscapes, and ideoscapes. These are 'five dimensions of global cultural flows. 48 None of these aspects of our current world can be captured completely in one single or simple notion. They all refer to complex, layered, and differentiated phenomena.

\section{McAlister's Religioscapes and Tweed's Sacroscapes}

Scholars of religion Elizabeth McAlister and Thomas Tweed, have both transferred Appadurai's notion of -scapes to religious studies. McAlister speaks of 'religioscapes' as 'the subjective religious maps - and attendant theologies - of immigrant, or diasporic, or transnational communities who are also in global flow and flux'49 Tweed speaks of religions as 'sacroscapes': 'religious flows' 'across time and space' that every now and then come to a temporary standstill here or there. ${ }^{50}$ Both analogies suggest that religions are connected to the local

\footnotetext{
45 J. Coulson, C.T. Carr, and L. Hutchinson, D. Eagle, eds., The Oxford Illustrated Dictionary, 2nd ed. (Oxford: Clarendon Press, 1978).

46 Arjun Appadurai, Modernity at large: Cultural dimensions of globalization, 2nd ed., Public Worlds 1 (Minneapolis: University of Minnesota Press, 1996), esp. 33-43.

47 See Manuel Castells, The Information Age: Economy Society and Culture, 3 vols. (Cambridge: Blackwell, 1996-200o), esp vol. 1, The Rise of the Network Society.

48 Thomas A. Tweed, Crossing and Dwelling. A Theory of Religion (Cambridge, Mass: Harvard University Press, 2006), 61.

49 Elizabeth McAlister, "Globalization and the Religious Production of Space", Journal for the Scientific Study of Religion 44, no. 3 (2005), 249-255, here 251.

Tweed, Crossing and Dwelling, 6if.
} 
as well as to global space and time. Neither Appadurai nor Tweed or McAlister use narrow definitions in their work, which is related to their approach of the subject of study. Scholars of religion and theology move through a landscape, across a field - in their case the field of religion - and as a consequence their theory is dynamic as well, Tweed claims:

Theory as embodied travel is not a stationary view of static terrain. It is not geography or chorography (...). Theory is purposeful wandering. (...) A theory of religion, as I understand, is not an omnispective map of the whole offered by a stationary observer. Theory is travel..$^{51}$

He adds that his notion of sacroscape 'only helps if we have aquatic and nonterrestrial analogies in mind. Sacroscapes (...) are not static. They are not fixed, built environments - as the illusion to landscape in the term might imply $(\ldots)^{\prime} \cdot 52$

We propose that the passion and other large ecclesial musical forms that have moved to the 'outer-ecclesial' domain can be understood within the frameworks that Appadurai, McAlister, and Tweed have built. The particular notion of sacro-soundscapes then naturally comes to the fore.

\section{Soundscapes in Acoustemology and Theology}

The concept of the 'soundscape' has been present in scholarly debates since the 1950s and finds its origin in the fields of culture and technology, music studies, and anthropological and ethnomusicological studies of 'acoustemology'.53 The musicological and anthropological notions of 'soundscape' appear to be those which are most relevant to explorations of religious experience and its sensual mediation, and the work of Steven Feld, professor of anthropology and music at the University of New Mexico, must be mentioned at this point. ${ }^{54}$ Feld's work has been described as 'a refined analysis of auditory space as a complex field of meanings that is closely related to spiritual and religious practices, to cosmology, and to a conceptual ordering of the world through material objects, practices, and social organization., ${ }^{55}$

\footnotetext{
$5^{1} \quad$ Tweed, Crossing and Dwelling, nff.

52 Tweed, Crossing and Dwelling, 61.

53 Dorothea E. Schulz, "Soundscape", in Key Words in Religion, Media and Culture, ed. David Morgan (New York: Abingdon, 2008), 176-186.

54 Steven Feld, "Waterfalls of Song: An Acoustemology of Place Resounding in Bosavi, Papua New Guinea", in Senses of Place, eds. Steven Feld and Keith H. Basso (Santa Fe, NM: School of American Research Press, 1996), 91-136.

55 Schulz, "Soundscape", 179.
} 
A focus on sound can also be traced in the discipline of theology. John McClure uses the term soundscape when writing about the invention of religious desire. Mixed and mastered sounds leave the recording studio and become part of a larger soundscape of music within the larger culture. McClure states that 'in large part, this soundscape is made up of music that accompanies us when we work, read, eat, relax, and travel. But this soundscape also includes other forms of media: television, Internet, podcasts, and so on, as well as the sounds of city and rural life, including automobiles, machinery, airplanes... ${ }^{56}$ Soundscape, McClure suggests, quoting aesthetic philosopher Gernot Böhme, is the ability to hear the 'musicality of the world itself': 'the feeling of 'home' is strongly mediated by the soundscape of a region, and the characteristic experience of a lifestyle, of the atmosphere of a city or area of countryside, is fundamentally determined in each instance by its acoustic space. ${ }^{57}$

In The Sound of Worship, a liturgical ethnography that sought to update the concept of 'church music', I came to conclusions similar to those of Feld and McClure, although I did not yet use the concept 'soundscape. 58 In using the broad concept of sound to investigate the sonic aspects of liturgy, instead of the somewhat limited concept of church music, I made clear that sound is 'linked up with performance and movement' and thus with 'embodiment. ${ }^{59}$ I asserted that the sonic practice of worship (which itself is an auditory space) as performed by congregations and parishes is a practice that becomes loaded with religious meanings closely related to cultural contexts and worldviews. Faith in worship is expressed by the performance of sound, while this performance, at the same time, inscribes faith into the bodies of participants.

According to sociocultural anthropologist Dorothea Schulz, Feld takes the notion of '-scape' very seriously when he posits the spatial as the starting place for the exploration of the role of bodily movement and sensual orientation in religious experience and mediation. Schulz subsequently claims that

56 John McClure, Mashup Religion. Pop Music and Theological Invention (Waco, TX: Baylor University Press, 2011), 109-122, here 117.

57 John McClure, Mashup Religion, 118.

$5^{8}$ Klomp, The Sound of Worship, 39.

59 I thank dr. Mark Porter for pointing out to me that the term 'church music' means very different things in different countries. Kirchenmusik in Germany tends to be a much more restricted and hierarchical phenomenon than church music in the UK. The study of kerkmuziek in the Netherlands long relied on a German understanding of the phenomenon, using German-language literature. I am referring to these 'limited' understandings of the concept here. 
because soundscape is closely related to body movement and sensation and anchors religious experience in the here-and-now, it implies a notion of localized 'scape' that differs from de-territorialized conceptualizations of 'scape', such as reflected in Appadurai's famous 'ethnoscape'.60

Schulz tends to see the notions of localised scapes and de-territorialised conceptualisations of scape in opposition. With Tweed, who speaks about crossing and dwelling, we, however, consider the two as inextricably connected, as we will now demonstrate.

\section{Sacro-Soundscapes}

In connection with Tweed's 'sacroscapes' and the use of 'soundscapes' in music-related studies, we propose the notion of 'sacro-soundscapes' to point to the sonic aspects of religions. These are understood as being in a state of constant flux, in a permanent flow, but also as 'dwelling' intermittently and at irregular times. ${ }^{61}$ The notion of 'sacro-soundscapes' refers to the movements of sacred sound through times and spaces. ${ }^{62}$ Psalms, hymns, spiritual songs, religious pop music, and large musical forms that stem from the Christian tradition (such as Masses, Requiems, Stabat Mater's and Passions) move across time and space: they originate in a specific place and time and move alongside the people who sing the songs, the musicians who play the music, and the customers who buy and/or download the music, and they find temporary dwellings, for example in hymnals, in the seasonal programs of choirs and orchestras, or in an event such as The Passion. Individual people, groups of friends or colleagues, congregations and parishes, and the crowds of people who attend festivals and events carry these various sounds along with them, cherish them, discuss them, reject them, leave them behind, and/or find them again. This whole complex of sacred sounds, their words and music, the way they are performed and accompanied, the context in which they are performed, the way they are appropriated, and the attributed meanings that peo-

\footnotetext{
6o Schulz, "Soundscape", 185 .

61 Cf. Castells, The Information Age, especially vol. 1, The Rise of the Network Society; Bauman, Liquid Modernity; Barnard, Cilliers and Wepener, Worship in the Network Culture.

62 So far we have spoken about 'ritual musical practices'. Our focus on sound (vs. music) here emphasizes that we do not limit people's sonic practices to the particular shape of music alone: a fixed focus on the particular shape of music would be inappropriate when developing a concept for the interpretation of fluid practices.
} 


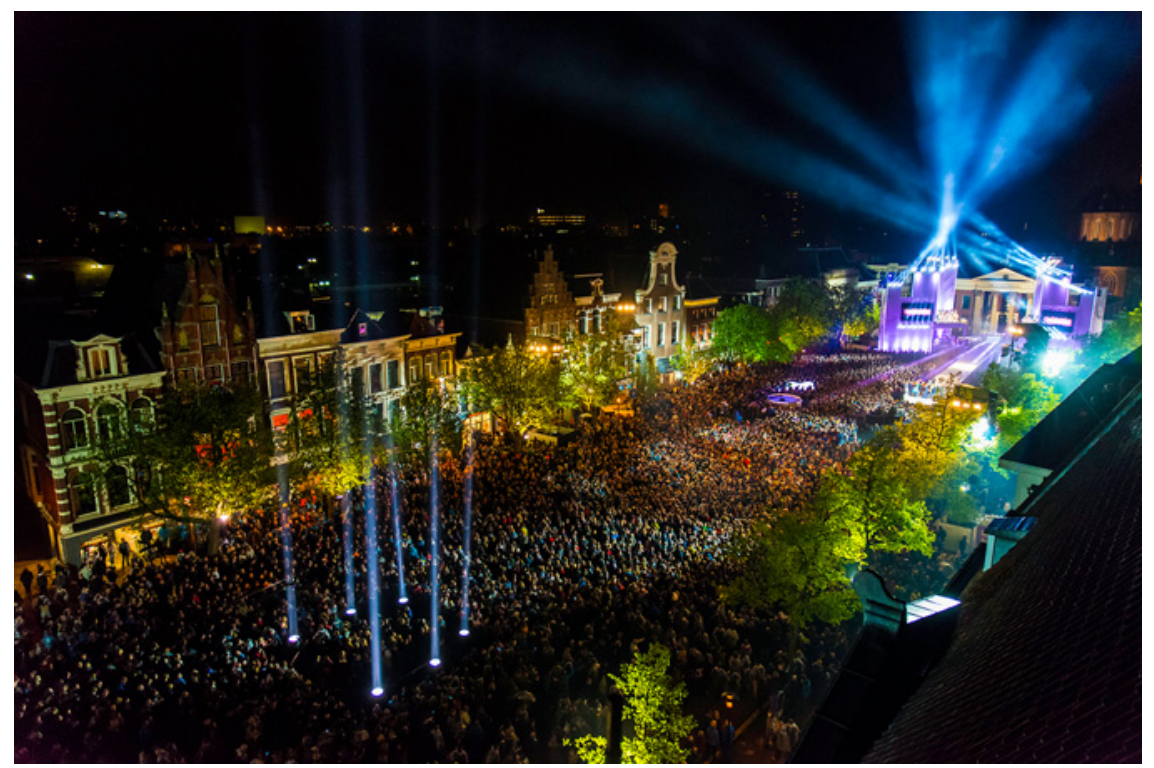

FIGURE 5 The temporary dwelling of a passion performed on the Grote Markt in the city of Groningen in 2014

PHOTO: WILLEM-JAN DE BRUIN

ple share, create a sacro-soundscape. ${ }^{63}$ In the particular case of The Passion, the 'secular' top hits placed within the framework of the passion narrative are loaded with new and sacred meanings, and make The Passion a temporary dwelling for a selected number of songs, a station, and a significant landmark in this soundscape. ${ }^{64}$ The changing and liquidising sacro-soundscape (de-territorialised -scape) became 'grounded' in the temporary dwellings of a passion performed in the city of Gouda in 2011, of Rotterdam in 2012, of Den

63 We develop the notion of the 'sacro-soundscape' in this chapter in order to refer to the transfer and transformations of practices of religious musical forms and repertoire. We do not use the concept in order to claim that musical forms from the Christian tradition automatically become sacred (cf. the next footnote), nor do we intend to limit sacrality to religious forms, as any practice or object can become the object of sacred meaning making.

64 Sacred meaning-making here is taken in a broad sense, based on an approach that looks beyond a divine presence in the direction of an actively constructed value within a particular meaning system, from which people in turn mix and match elements to their own convenience and liking. This is further elaborated in Wijnia and Klomp, "Tarenskeen's LUTHER". 
Haag in 2013 and so forth (localised scape). So, elements of a sacro-soundscape (repertoire, musical forms, psalms and hymns, etc.) travel across domains and find temporary local dwellings that anchor religious experience in the hereand-now.

\section{The Study of Sacro-Soundscapes}

One consequence of the development of Dutch society - and presumably of other Western societies - beyond the church, beyond institutionalised religion, and possibly even beyond religion, is that our universities and faculties are now developing into institutions that move beyond theology and, at the same time, also beyond religious studies. That does not mean that religion is no longer studied, but rather that theology and religious studies have become part of larger research consortia, or at least have moved closer to the humanities. As a consequence, we have also moved beyond the classical study of sacred sound: hymnology, which singled out Christian congregational music, whilst leaving all other sacred music to ethnomusicology. ${ }^{65}$

When we consider classical hymnology as part of practical theology or liturgical studies, we must account for the shift that has occurred in these disciplines over the past three decades. We can see that practical theology today in our context is often akin to public theology, whereas liturgical studies are referred to as liturgical ritual studies or is seen as (a part of) ritual studies. Practical theology defines its task mainly as a theological reading of practices of faith in a broad domain, and the inner-ecclesial domain is investigated as part of a

65 At least, in the German- and Dutch-speaking context. The definition of hymnology in the entry on the same subject given by Marcus Jenny, "Hymnologie", in Theologische Realenzyklopaedie, eds. Gerhard Krause and Gerhard Müller (Berlin: De Gruyter, 1986), 15: $770-778$, may serve as an example of how the discipline was perceived: as a practical theological discipline, more specifically as part of liturgical studies. According to Jenny, linguistics and musicology are its main supporting disciplines outside theology. More specifically, he defines hymnology as 'the study of Christian hymns in all their forms and expressions and at all times'. It includes the study of hymns and anthems as well as of Gregorian chant. Further it comprises hymnal studies - defined as 'an auxiliary discipline for the editing of hymnals' - church music, theology of church music and the practical training of church musicians. Its object is church hymns and church music, from a fundamental and from a practical perspective, as well as non-strophic, non-metrical and non-rhythmic forms of church music and sung texts. In summary, the focus of hymnology is on church music and texts that are sung in churches and worship services. 
broader field. ${ }^{66} \mathrm{~A}$ sacro-scape has developed that does not respect the boundaries of churches and denominations, but that is highly fluid. ${ }^{67}$ The church is a landmark or a discrete phenomenon in a wide sacro-scape, and it is studied as such. The same holds for liturgical ritual. Many studies have shown that liturgical ritual stands in a dynamic relationship to a liquefied culture. ${ }^{68}$ The topic of liturgical ritual studies now becomes the ritual and symbolic aspects of these sacro-scapes, and the topic for the successor of hymnology becomes the sound aspect of sacro-scapes. In short it researches sacro-soundscapes.

\section{Conclusion}

In this chapter, we have developed a notion of sacro-soundscapes in close connection with the work of cultural anthropologists, ethnomusicologists, historians, theologians, and religious studies scholars. Sacro-soundscapes do not

66 We are aware of discussions, such as those published in the International Journal of Practical Theology 16, no. 1 (2012), on what practical theology actually is. These clearly demonstrate that there is no shared understanding of this discipline. What is presented here is our view of the discipline.

67 Cf. Pete Ward, Participation and Mediation: A Practical Theology for the Liquid Church (London: SCM Press, 2008), where the author claims that in order to make sense of the contemporary nature of the church it is crucial to understand in what way cultural expression mediates that encounter with God.

68 We here mention a couple of relevant research projects on sacro-soundscapes that have been performed in the Netherlands since 20o6. Dr. Martin Hoondert (Tilburg University), in his $\mathrm{PhD}$ thesis Om de parochie. Ritueel-muzikale bewegingen in de marge van de parochie. Gregoriaans, Taizé, Jongerenkoren (Heeswijk: Abdij van Berne, 2006), concludes that the margin of the parish has increasingly developed into a locus for new liturgical and musical initiatives, whereas the core parish has stayed behind by sticking to the old. The sacro-scape has innovative musical qualities, but these are not located in the traditional churches. Hoondert is currently investigating Requiem concerts in Dutch culture and musical repertoires used at funerals, and is supervising a research project by Janieke Bruin-Mollenhorst MA (Tilburg University) on music during cremation rituals. I myself have also investigated the margin as a breeding ground for innovation in a study on the performance of sound in two migrant churches in Amsterdam (Protestant Theological University). My research on the liturgy of immigrant churches has suggested several qualities of sound: notions that refer to the open and fluid, much more than to the strict, closed and denominational. See Klomp, The Sound of Worship. Dr. Hanna Rijken (Protestant Theological University) has studied the popularity of English evensong - as worship or as a concert - in the Netherlands, and its appropriation by visitors, choir members, pastors, and musicians. See Hanna Rijken, "My Soul Doth Magnify'. The Appropriation of the Anglican Choral Evensong in the Netherlands" (PhD thesis Protestant Theological University, Amsterdam, 2017). Dr. Lieke Wijnia has investigated Festival Musica Sacra Maastricht, focusing on experiences of sacrality in contemporary culture through music. See Wijnia, Making Sense. 
respect the boundaries of churches or denominations, but are highly fluid. The concept enables us to better understand musical practices in a liquefied religious landscape, as it takes the fluidity of these practices into account as well as the contexts in which they are performed. Religion in general has become fluid, and so has the study of religious objects and practices, as the changing position of theology and religious studies in academic life shows. In our view, research on these fluid practices calls forth a surpassing of the traditional sub-disciplines of practical theology. Practical theology nowadays largely deals with faith practices within broad sacro-scapes. It has predominantly moved beyond church-centred liturgical, catechetical, congregation$\mathrm{al}$, and pastoral studies. It has moved into the study of sacro-scapes that are approached from symbolic and ritual perspectives, from perspectives of formative or learning processes, of community formation, and of care. Musical theological perspectives have, consequently, also moved beyond hymnology in its classical understanding as their main site.

Our updated and broadened definition of the field of sacred music has consequences for our understanding of the field of study: the 'original' field has changed. From the moment singing became an element inherent to liturgy in the first centuries $\mathrm{CE}$, there has always been something like hymnological reflection. ${ }^{69}$ Christian hymnology, as a result, developed to focus on ecclesial singing, later coming to include the systematic collection of Christian hymnbooks. In 21st century network societies, where performances of large-scale Christian musical forms are no longer confined to churches and congregations, and where the sonic aspects of religions are understood as being in a constant flux and a permanent flow, the field of study is becoming more expansive. The inner-ecclesial domain in this context is to be researched as part of a broader field or, indeed, as part of a sacro-soundscape. This requires openness toward 'extra-ecclesial' musical practices in any field of study that regards practices of Christian music. It requires openness towards fluid musical expressions of religiosity, for instance towards the (more or less ad hoc) groups of people participating in The Passion, in sing-along Messiahs, or in choral evensong concerts. And it requires openness towards musical festivals or events - be it 'Christian' or 'sacred' or based on a particular music style and towards those whose names are not on church membership lists, but who take part in any practice of music and may identify or encounter God or the sacred. If practical theologians want to study religion and new quests for God in a society 'after God', maximum openness is required concerning the practices they choose as their objects of study. In the following chapters, we will see the yield of this broader approach.

69 Jenny, "Hymnologie", 77o. 